УДК 343

DOI https://doi.org/10.51989/NUL.2021.4.33

\title{
ХАРАКТЕРИСТИКА ПРАВА ОСОБИ НА ПУБЛІЧНИЙ СУДОВИЙ РОЗГЛЯД У КРИМІНАЛЬНОМУ ПРОВАДЖЕННІ
}

\author{
Ковальська Дарія Тарасівна, \\ аспірант кафедри кримінального процесу і криміналістики \\ юридичного факультету \\ Львівського національного університету імені Івана Франка
}

У статті подано короткий аналіз загальних рис декількох елементів права особи на публічний судовий розгляд кримінального провадження. Доцільність такого аналізу пояснюється тим, що право особи на публічний судовий розгляд кримінального провадження як складова частина права на справедливий суд відіграє важливу роль у кримінальній процесуальній діяльності у зв'язку з побудовою України як правової держави й утвердженням позиції захищеності осіб, які потрапляють у сферу кримінального провадження. Досліджуваний комплекс прав особи також тісно пов'язаний із засадами кримінального провадження, що визначають його зміст і спрямованість.

Характеристика таких елементів, як право на усність кримінального провадження та на особисту присутність під час судового розгляду, право на відкритість судового розгляду, публічне проголошення судових рішень і доступ громадськості до його рішень, право особи на публічний розгляд кримінального провадження, актуальна не лише для теорії кримінального процесу, а й для практики провадження в кримінальних справах. Усність кримінального провадження в статті схарактеризовано через призму інстанційності судів: присутність під час судового розгляду в суді першої інстанції та суді апеляційної інстанції. У контексті аналізу доступу громадськості до судових рішень подано пропозицію наукового визначення поняття «громадськість». Визначення поняття уможливить розуміння, хто ж має доступ до судових рішень.

У статті наведено приклад рішень Європейського суду з прав людини з метою зазначення порушення / відсутності порушень права особи на публічний судовий розгляд кримінального провадження, взявши за основу конкретний, вищезазначений елемент такого права.

Ознайомлення з кримінальним процесуальним законодавством європейської країни Польщі в контексті права особи на публічний судовий розгляд кримінального провадження допомогло сформувати думки щодо доцільності / недоцільності імплементування відповідних норм у національне законодавство.

Тематика, безумовно, актуальна, оскільки права особи в кримінальному провадженні формулюють і визначають основоположні ідеї всієї кримінальної процесуальної діяльності. Водночас право особи на публічний судовий розгляд кримінального провадження та його елементи не досить вивчене в науці вітчизняного кримінального процесуального права.

Ключові слова: право особи, публічний судовий розгляд, судовий розгляд, кримінальне провадження, усність, особиста присутність, публічність, судове рішення, громадськість.

\section{Kovalska Dariia. Characteristics of the human right to public trial in criminal proceedings}

The article analyzes several elements of a person's right to a public trial in criminal proceedings. The expediency of the analysis is explained by the fact that the right of a person to a public trial of criminal proceedings plays an important role in criminal - procedural activities in connection with the construction of Ukraine as a state governed by the rule of law. It is important to analyze several elements of the person's right, which is one of the main principles of criminal proceedings. The subjects of criminal proceedings should be given by law and provided by the state bodies conducting the process, the freedom to choose the option of behavior to pursue their own interests in a criminal case.

Characteristics of such elements as the right to oral criminal proceedings and to be present personally during the trial; the right to open trial; public proclamation of court decisions and public access to its decisions of the person's right to public criminal proceedings is relevant not only for the theory of criminal procedure, but also for the practice of criminal proceedings. 
The orality of the criminal proceedings in this article is characterized through the prism of the instance of the courts: the presence during the trial in the court of first instance and the court of appeal. In the context of the analysis of public access to court decisions, a proposal for a scientific definition of the term "public" is presented. The definition of this concept will make it possible to understand: who has an access to court decisions.

The article provides an example of decisions of the European Court of Human Rights in order to indicate the violation / absence of violations of the right of a person to a public trial in criminal proceedings, based on a specific, above, element of this right.

Familiarization with the criminal procedure legislation of the European country - Poland in the context of the right of a person to a public trial in criminal proceedings helped to form opinions on the expediency / inexpediency of implementing the relevant rules in national law.

This topic is certainly relevant, because the rights of the individual in criminal proceedings formulate and determine the basic ideas of all criminal proceedings. At the same time, the person's right to a public hearing of criminal proceedings and its elements are insufficiently studied in the science of domestic criminal procedural law.

Key words: right of the person, public trial, criminal proceedings, oral, personal presence, publicity, court decision, public.

Згідно із ч. 2 ст. 1 Кримінально-процесуального кодексу України (далі - КПК) кримінальне процесуальне законодавство України складається з відповідних положень Конституції України, міжнародних договорів, згода на обов'язковість яких надана Верховної Радою України, цього Кодексу й інших законів України. 17 липня 1997 р. Верховна Рада України ратифікувала Конвенцію про захист прав людини та основоположних свобод 1950 р., яка набрала чинності для України 11 вересня 1997 р. Внаслідок цього кожна фізична особа, неурядова організація або група осіб, що знаходяться під юрисдикцією України, отримали право після використання всіх національних засобів правового захисту звертатися зі скаргою про порушення Україною прав і свобод, гарантованих конвенцією, до Європейського суду з прав людини - однієї із найбільш поважних і впливових міжнародних установ [1, с. 7]. Саме ст. 6 пар. 1 Конвенції про захист прав людини й основоположних свобод (далі - Конвенція), передбачено право на справедливий суд: кожен має право на справедливий суд і публічний розгляд його справи упродовж розумного строку незалежним і безстороннім судом, встановленим законом, який вирішить спір щодо його прав та обов'язків цивільного характеру або встановить обґрунтованість будь-якого висунутого проти нього кримінального обвинувачення.

Варто зазначити, що публічність провадження захищає від таємного правосуддя, на яке не поширюється контроль громад- ськості. Також вона $€$ одним із засобів, який допомагає зберегти довіру до судів. Завдяки прозорості, яку вона надає відправленню правосуддя, публічність дозволяє втілювати мету ст. 6 пар. 1 - справедливий судовий розгляд, гарантованість якого $є$ одним із принципів кожного демократичного, у розумінні Конвенції, суспільства. Про це йдеться на сторінках 55-56 у посібнику зі ст. 6 Конвенції про захист прав людини й основоположних свобод «Право на справедливий суд (кримінальний процесуальний аспект)».

Очевидно, право особи на публічний судовий розгляд кримінального провадження $\epsilon$ складовою частиною права на справедливий суд. На підставі аналізу нормативно-правових актів та наукової літератури з досліджуваного питання, серед елементів права особи на публічний судовий розгляд кримінального провадження варто виокремити: право на усність кримінального провадження та на особисту присутність під час судового розгляду, право на відкритість судового розгляду, право на публічне проголошення судових рішень і доступ громадськості до його рішень.

Аналізуючи право на усність кримінального провадження варто зауважити, що в національному законодавстві $€$ норма: ч. 1 ст. 23 КПК України, яка передбачає, що суд досліджує докази безпосередньо. Показання учасників кримінального провадження суд отримує усно. Допит обвинуваченого, потерпілого, свідка, експерта проводиться усно відповідно до ст. ст. 351-354, 356 КПК [2, с. 84]. 
У вказаних статтях йдеться про загальну процедуру допиту вищезазначених учасників кримінального провадження без зазначення способу допиту. Норми варто вдосконалити, зазначивши про необхідність проведення його в усній формі, уникнувши ймовірного порушення права на усність кримінального провадження.

Право на особисту присутність під час судового розгляду пропоную поділити на два види, за основу яких взята інстанційність судів: присутність під час судового розгляду в суді першої інстанції та суді апеляційної інстанції.

Присутність під час судового розгляду в суді першої інстанції полягає в такому. Принцип публічних судових засідань і відкритих судових слухань $\epsilon$ особливо важливим тоді, коли особа, обвинувачена у вчиненні кримінального правопорушення, повинна взагалі мати можливість бути присутньою на слуханнях у суді першої інстанції.

Прикладом порушення вказаного принципу є справа Юсілла (JUSSILA) проти Фінляндії: рішення Європейського суду з прав людини у справі від 23 листопада 2006 р. (пар. 40). Згідно із цим судовим рішенням усне, публічне слухання складає фундаментальний принцип, закріплений у ст. 6 §. 1. Також на думку суду, цей принцип $€$ особливо важливим у кримінальному провадженні, а також у суді першої інстанції, що повністю відповідає вимогам ст. 6. Заявник також має право слухати свою справу з можливістю подавати докази для виправдання, досліджувати докази, допитувати чи перехресно допитувати свідків [3].

Присутність під час судового розгляду у суді апеляційної інстанції. 3 категорії «публічності судових дебатів» випливає право обвинуваченого бути вислуханим особисто в суді апеляційної інстанції. Таким чином, принцип публічності судових дебатів має на меті забезпечити обвинуваченому права на захист.

Прикладом порушення права на особисту присутність під час судового розгляду у суді апеляційної інстанції є справа Тьєрс та інші проти Сан-Маріно, рішення по якій ухвалено у Страсбурзі 25 липня 2000 р.. Європейський суд з прав людини постановив, що мало місце порушення ч. 1 ст. 6 Конвенції 7 травня 1993 р. за вчи- нення шахрайства і незаконного заволодіння майном заявника було засуджено до позбавлення волі з відстрочкою виконання вироку, а також до сплати штрафу. Суддя, який проводив судове слідство і вирішував справу по суті у суді першої інстанції, готував матеріали для слухання справи заявника у порядку апеляційного провадження. Під час слухання справи в апеляційному суді заявника не було викликано для дачі свідчень. Апеляційний суд залишив у силі вирок суду першої інстанції. Усі заявники оскаржували ненадання їм можливості дати свідчення під час слухання їхніх справ апеляційним судом, що, на їхню думку, $\epsilon$ порушенням ч. 1 ст. 6 Конвенції. Тому Суд дійшов висновку про те, що мало місце порушення ч. 1 ст. 6 Конвенції. На думку Суду, принцип гласності судового розгляду включає дотримання двох вимог:

а) судові слухання справи мають бути відкритими;

б) вироки суду повинні проголошуватися публічно.

Питання дотримання лише першої із цих вимог стало предметом розгляду Суду [4].

Проте, особиста присутність підсудного під час провадження в суді апеляційної інстанції не має такого ж вирішального значення, як в суді першої інстанції. Умови застосування ст. 6 Конвенції стосовно провадження в суді апеляційної інстанції залежить від особливостей здійснення правосуддя в національній правовій системі, а також ролі, яку відіграє в ньому суд апеляційної інстанції [5, с. 59].

Наприклад, це зображено у справі Ермі (HERMI) проти Італії (§ 60): рішення Європейського суду з прав людини від 18 жовтня 2006 р. Обвинувачений був повідомлений про слухання справи в суді апеляційної інстанції, але не з'явився. Судові органи влади розцінили цю відсутність як відмову від його права особисто приймати участь у слуханні: порушення немає [6].

У національному законодавстві України ст. 405 КПК України визначено, що неприбуття сторін або інших учасників кримінального провадження не перешкоджає проведенню розгляду, якщо такі особи були належним чином повідомлені про дату, час і місце апеляційного розгляду та не повідомили про поважні причини 
свого неприбуття. Якщо для участі в розгляді в судове засідання не прибули учасники кримінального провадження, участь яких згідно з вимогами КПК або рішенням суду апеляційної інстанції $€$ обов'язковою, апеляційний розгляд відкладається.

Тобто законодавцем розроблено норму яка містить вимогу дотримання принципу публічності судового розгляду в контексті присутності особи під час розгляду апеляції.

Аналізуючи публічність проголошення вироків в українському законодавстві, варто зазначити, що відповідно до п.п. 1, 2 ст. 376 КПК України судове рішення проголошується прилюдно та негайно після виходу суду з нарадчої кімнати. Головуючий у судовому засіданні роз'яснює зміст рішення, порядок і строк його оскарження. Якщо складання судового рішення у формі ухвали (постанови) вимагає значного часу, суд має право обмежитися складанням і оголошенням його резолютивної частини, яку підписують всі судді. Повний текст ухвали (постанови) повинен бути складений не пізніше п'яти діб з дня оголошення резолютивної частини й оголошений учасникам судового провадження. Про час оголошення повного тексту ухвали (постанови) має бути зазначено в раніше складеній ії резолютивній частині.

Вирок або інше судове рішення оголошується обов'язково в присутності обвинуваченого й усіх учасників судового провадження. Навіть у випадку, коли обвинувачений за порушення порядку судового засідання був видалений на весь час судового розгляду, судове рішення, яким закінчено провадження в суді, негайно оголошується обвинуваченому після його ухвалення (4. 1 ст. 330 КПК). Відсутність у залі інших учасників судового розгляду не $\epsilon$ перешкодою для оголошення вироку [7].

Європейським судом ухвалено кілька рішень, які присвячені безпосередньо розгляду питання змісту вимоги п. 1 ст. 6 Конвенції щодо публічності проголошення судового рішення. Визначальним в цьому $\epsilon$ рішення Претто ( PRETTO) та інші проти Італії : рішення Європейського суду з прав людини (далі - ЄСПЛ) від 04 березня 2003 р. [8], в якому Суд прямо встановив, що він не зобов'язаний приймати дослівне тлумачення виразу "pronounced publicly / rendu publiquement", закріпленому в оригінальних (англійській і французькій) версіях п. 1 ст. 6 Конвенції [9, с. 47-48].

На перший погляд, положення п. 1 ст. 6 Конвенції викладено конкретніше, ніж положення п. 1 ст. 14 Міжнародного пакту про громадянські та політичні права 1966 р., в якому передбачено, що судове рішення shall be made public - «має бути публічним» (фp. - sera public) [10].

Зміст вказаного поняття трактується у справі Шутер (SUTTER) проти Швейцарії: рішення ЄСПЛ від 22 лютого 1984 р., у якому Суд зазначив, що «<...> автори Конвенції не могли залишити поза увагою цей факт, що хоч це й не простежується в їхніх підготовчих матеріалах так само чітко, як в аналогічних матеріалах до Пакту 1966 р.» [11]. Суд визнав для себе необов'язковість дослівного тлумачення формулювання Конвенції та встановив необхідність в кожному окремому випадку форму оприлюднення судового рішення визначати на підставі національного права держави - відповідача, залежно від особливостей конкретного провадження і відповідно до зазначеної цілі та завдання п. 1 ст. 6.

Перш ніж дослідити принцип доступу громадськості до судових рішень, варто проаналізувати поняття «громадськості». Законодавець такого суб'єкта, як «громадськість», не визначає. Натомість у національному законодавстві $\epsilon$ ряд нормативноправових актів, у контексті норм яких застосовується це поняття. Наприклад, в Законі України «Про культуру» визначено термін «культурно-мистецька громадськість» як митці й працівники закладів культури, інші працівники, об'єднані в професійні творчі спілки, національні культурні товариства [12, ст. 1].

У ст. 11 Закону України «Про виконавче провадження» виокремлює поняття «громадськість за місцем проживання». У ст. 8 Закону України «Про Військову службу правопорядку у Збройних Силах України» йдеться про «громадськість за місцем служби або роботи». Орхунська конвенція постановляє, що «громадськість» означає одну або більше фізичних чи юридичних осіб, їхнє об'єднання, організації або групи, які діють згідно з національним 
законодавством або практикою [13, п. 4 ст. 1]. У Конвенції вживається також термін «зацікавлена громадськість» - громадськість, на яку справляє або може справити вплив процес прийняття рішень із питань, що стосуються навколишнього середовища, або яка має зацікавленість у цьому процесі [14, с. 100].

Відповідно до Словника української мови громадськість - це передова частина, передові кола суспільства [15, с. 175]. Як критично зауважує Ярослав Журовський, словник наголошує на «передовому» характері й фактично звужує таке широке поняття (широку громадськість) до кола «передових» [16].

В юридичній енциклопедії міститься теоретичне визначення «громадськості» як соціально активної частини суспільства, яка на добровільних засадах бере активну участь у суспільно-політичному житті країни. Для громадськості властиві: потреба у комунікації, колективна діяльність, перевага громадських інтересів над приватними, активне вираження своєї активної позиції тощо. Важливою сферою діяльності громадськості $\epsilon$ їі участь у державно-правових заходах [17, с. 640].

У навчальному посібнику Ф. Джефкінса й Д. Ядіна з публічних відносин, громадськість, не зважаючи на складність соціально-класової системи, автори поділяють на 10 основних категорій, які притаманні будь - якій цільовій аудиторії:

1) суспільство;

2) потенційні співробітники;

3) співробітники;

4) постачальники матеріалів і послуг;

5) інвестори, фінансовий ринок;

6) дистриб'ютори;

7) споживачі, користувачі;

8) лідери громадської думки;

9) громадські організації;

10) засоби масової інформації [18, с. 56].

Тож, проаналізувавши законодавчі та наукові термінологічні підходи, громадськість можна визначити як одна або більше фізичних чи юридичних осіб, їхнє об'єднання організації або групи, які на добровільних засадах, межах законодавства, беруть активну участь у суспільнополітичному житті країни.

Визначення поняття «громадськості» й категорій, які охоплюють це поняття, необхідне в контексті розуміння, хто ж має право на доступ до судових рішень.

Зауважу, що основними міжнародними документами, які регулюють порядок доступу до судових рішень та які ратифіковані Україною $є$ Конвенція Ради Європи про доступ до офіційних документів, ст. 6 Конвенції про захист прав людини та основоположних свобод. Відповідно до Закону України «Про міжнародні договори України», чинні міжнародні договори України підлягають сумлінному дотриманню Україною відповідно до норм міжнародного права.

Далі слід надати загальну характеристику забезпечення доступу громадськості до рішень суду в контексті Закону України «Про доступ до судових рішень», норми якого згадувались. Проаналізувавши цей Закон, можна виокремити чотири напрямки доступу громадськості до судових рішень:

1) проголошення судового рішення в залі судового засідання (ст. 2 Закону України «Про доступ до судових рішень»);

2) оприлюднення судових рішень в Єдиному державному реєстрі судових рішень (ст. 3 Закону України «Про доступ до судових рішень»);

В Україні практикується загальний доступ до окремих текстів рішень Конституційного Суду, Верховного Суду через офіційні вебпортали цих судів. А з 2006 р. для доступу до судових рішень судів загальної юрисдикції Державна судова адміністрація на виконання Закону України «Про доступ до судових рішень» відкрила Єдиний державний реєстр судових рішень. Єдиний державний реєстр судових рішень (далі - ЄРДР) є автоматизованою системою збирання, зберігання, захисту, обліку, пошуку та надання електронних копій судових рішень. Порядок ведення Реєстру затверджений постановою Кабінету Міністрів України № 740 від 25 травня 2006 р. [19, с. 17];

3) офіційне опублікування судових рішень у друкованих виданнях, за умови посвідчення органом, який забезпечує ведення Реєстру, відповідності судових рішень оригіналам або електронним копіям судових рішень, внесених до Реєстру (ст. 5 Закону України «Про доступ до судових рішень»). 
Тексти судових рішень публікуються в різноманітних збірниках, періодичних виданнях судів, зокрема: «Судова апеляція», «Вісник господарського судочинства», «Вісник Вищого адміністративного суду України», «Вісник Верховного Суду України», «Рішення Верховного Суду України», «Вісник Конституційного Суду України», а також у правничих журналах і газетах: «Юридичний вісник України», «Юридична газета», «Правовий тиждень», «Закон і бізнес» та інші [20, с. 29];

4) забезпечення доступу до матеріалів провадження та надання копії рішення за зверненням особи, яка не бере (не брала) участі в провадженні (ст. 9 Закону України «Про доступ до судових рішень»).

В контексті дослідження доступу громадськості до рішень суду варто порівняти з аналізом доступу до суду першої інстанції «цивільного характеру». Стосовно питання доступу до суду, Суд повторює, що процедурні гарантії, закріплені ст. 6 (йдеться про ст. 6 Конвенції), гарантують кожному право подання скарги щодо його прав та обов'язків цивільного характеру до суду чи органу правосуддя. Таким чином, втілюється право на звернення до суду, одним з аспектів якого $€$ право доступу, тобто право розпочати провадження у судах. Суд наголошує, що право на звернення до суду, одним з аспектів якого $\epsilon$ право доступу до суду, не $\epsilon$ абсолютним, воно може бути обмеженим $[20$, c. 46]. Це зображено в справі «Голдер проти Сполученого Королівства», рішення від 21 лютого 1975 р.

Вважаю за доцільне навести приклад застосування елементів, що характеризують права особи на публічний судовий розгляд кримінального провадження в кримінальному законодавстві європейської країни, наприклад, Республіки Польща. Угодою про асоціацію між Україною та Європейським Союзом передбачено посилення співробітництва у сфері юстиції, свободи та безпеки з метою забезпечення верховенства права та поваги до прав людини і основоположних свобод (ст. 8), зміцнення судової влади, підвищення ії ефективності, гарантування ії̈ незалежності та неупередженості (ст. 14), взаємна правова допомога, приєднання до відповідних міжнародних документів $\mathrm{OOH}$ і Ради Європи [21].
Одним із членів Європейського Союзу з 2004 р. Є Республіка Польща. Кримінальне процесуальне право країни регулюється Конституцією Республіки Польща, Кримінальним процесуальним кодексом зі вступними положеннями, ратифікованими міжнародними угодами, системними нормами, що визначають організацію судів, прокуратури, адвокатури, юрисконсультів, правоохоронних органів, положеннями Цивільного процесуального кодексу в обсязі, визначеному Кримінальним процесуальним кодексом (ст. ст. 89, 107 пар. 2, ст. 292 пар. 1 і ст. 558 КПК).

Відповідно до ч. ч. 1, 2 ст. 45 Конституції Республіки Польща Кожен має право на справедливий, відкритий і без необґрунтованого перенесення розгляд справи компетентним, незалежним і неупередженим судом. Відмова від відкритого розгляду справи можлива з моральних причин, із міркувань безпеки держави й публічного порядку, а також із метою охорони приватного життя сторін або іншого важливого приватного інтересу. Судовий вирок оголошується публічно [22, с. 24].

Відкритість та усність основного слухання кримінального провадження $\epsilon$ одними із важливих засад кримінального процесу Польщі, передбачені Кримінальним процесуальним кодексом Польщі, зокрема Гл. 42 «Відкритість основного слухання» (Rozdział 42 Jawność rozprawy głównej) та Гл. 43 «Загальні положення про основне слухання» (Rozdział 43 Przepisy ogólne o rozprawie głównej). Відповідно до ст. 355 «Принцип відкритого слухання» Р. 42 Кримінального процесуального кодексу Польщі Слухання проводиться відкрито. Обмеження відкритості визначається законом (Art. 355.[Zasada jawności rozprawy] Rozprawa odbywa się jawnie. Ograniczenia jawności określa ustawa. Відповідно до ст. 356 «Публічність - правила слухання» Р. 42 КПК Польщі:

1) на слуханні, крім осіб, які беруть участь у провадженні, можуть бути присутні неозброєні повнолітні;

2) головуючий суддя може дозволити неповнолітнім та особам, зобов'язаним носити зброю, бути присутніми на слуханні;

3) не можуть бути присутніми на слуханні особи, які є несерйозними до суду. 
(Art. 356. [Publiczność - zasady obecności] §1. Na rozprawie oprócz osób biorących udział w postępowaniu moga być obecne tylko osoby pełnoletnie, nieuzbrojone. § 2. Przewodniczący może zezwolić na obecność na rozprawie małoletnim oraz osobom obowiazanym do noszenia broni. § 3. Nie moga być obecne na rozprawie osoby znajdujące się $\mathrm{w}$ stanie nielicującym z powagą sądu)

Відповідно до ст. 365 «Принцип усного слухання» Гл. 43 КПК Польщі, Слухання проводяться усно. (Art. 365. [Zasada ustności rozprawy] Rozprawa odbywa się ustnie) [23].

За результатами проведеного дослідження можна сформувати заключні положення: право особи на публічний судовий розгляд кримінального провадження $\epsilon$ еле- ментом права на справедливий суд в контексті ст. 6 §. 1 Конвенції про захист прав людини й основоположних свобод. Серед елементів, які характеризують це право $\epsilon$ : право на усність кримінального провадження та на особисту присутність під час судового розгляду, публічне проголошення судових рішень та доступ громадськості до його рішень. Прогалини процесуального законодавства України слід заповнити шляхом створення нових норм , зокрема в КПК України подати визначення понять «право особи на публічний судовий розгляд кримінального провадження» та «громадськість». Також визначити елементи такого права. Не виключення імплементації норм із кримінального процесуального законодавства європейських держав, враховуючи інтеграційний шлях України до ЄС.

\section{ЛITEPATУРА:}

1. Тлумачення та застосування Конвенції про захист прав людини й основоположних свобод Європейським судом із прав людини й судами України : навчальний посібник / авт. кол. : М.В. Мазур, С.Р. Тагієв, А.С. Беніцький, В.В. Кострицький ; Відп. ред. канд. іст. наук, доц. В.М. Карпунов. Луганськ : РВВ ЛДУВС, 2006. С. 7.

2. Кримінальний процесуальний кодекс України : Науково-практичний коментар / Відп. ред. : С.В. Ківалов, С.М. Міщенко, В.Ю. Захарченко. Харків : Одіссей, 2013. С. 84.

3. Юсілла (JUSSILLA) проти Фінляндії : Рішення Європейського суду з прав людини у справі від 23 листопада 2006 р. (§ 40). URL: http://europeancourt.ru/uploads/ECHR_Jussila_v_ Finland_23_11_2006.pdf.

4. Тьєрс та інші проти Сан-Маріно : Рішення Європейського суду з прав людини у справі від 25 травня 2000 р. База даних «Законодавство України». URL: https://zakon.rada.gov.ua/ laws/show/980_001\#Text.

5. Посібник Європейського суду з прав людини зі статті 6 Конвенції про захист прав людини й основоположних свобод (право на справедливий суд, кримінально-правовий аспект), оновлений 31 квітня 2019 р. Європейський суд з прав людини. C. 59. URL: https:// www.echr.coe.int/Documents/Guide_Art_6_criminal_UKR.pdf.

6. Ермі (HERMI) проти Італії : Рішення Європейського суду з прав людини у справі від 18 жовтня 2006 p. (§ 60). URL: http://hudoc.echr.coe.int/fre?i=001-119753.

7. Ківалов С.В., Міщенко С.М., Захарченко В.Ю. Кримінальний процесуальний кодекс України : Науково-практичний коментар. Харків : Одіссей, 2013. С. 743.

8. Претто (PRETTO) і ін. проти Італії : Рішення Європейського Суду з прав людини від 8 грудня 1983 р., п. 26. «Практика Європейського Суду з прав людини. Рішення. Коментарі». 2005. № 1.

9. Маляренко А.О. Поняття і сутність прилюдного проголошення судового рішення у світлі практики Європейського суду з прав людини. Вісник Академії адвокатури України. 2010. № 1 (17). С. 47-48.

10. Міжнародний пакт про громадянські та політичні права 1966 року. Бюлетень Міністерства юстиції України. 2002. № 1.

11. Підготовчі матеріали до Європейської Конвенції з прав людини та основних свобод 1950 року (Travaux preparatoires : Rights to a fair trial \# DH (56)11 CDH (68) 3). URL: https:// www.echr.coe.int/LibraryDocs/Travaux/ECHRTravaux-ART6-DH(56)11-EN1338886.PDF.

12. Про культуру : Закон України від 14 грудня 2012 р. № 2778-VI (у редакції від 16 липня 2020 р.) / Верховна Рада України. URL: https://zakon.rada.gov.ua/laws/show/2778-17\#Text. 
13. Конвенція про доступ до інформації, участь громадськості в процесі прийняття рішень та доступ до правосуддя з питань, що стосуються довкілля : Міжнародний документ від 25 червня 1998 р. (у редакції від 27 травня 2005 р.). База даних «Законодавство України». URL: https://zakon.rada.gov.ua/laws/show/994_015\#Text.

14. Мороз Г.В. Визначення поняття «громадськість» у контексті природоохоронної діяльності. Право України. 2004. № 8. С. 100.

15. Словник української мови : в 11 томах. Том 2, 1971. C. 175. URL: http://sum.in.ua/s/ ghromadsjkistj.

16. Жукровський Я.І. Загравання з публічністю, або Хто така «громадськість» і з чим її їдять. Закон і бізнес. 5-11 липня 2014 р. № 27. URL: https://zib.com.ua/ua/91975hto_taka_ gromadskist_i_z_chim_ii_idyat.html.

17. Юридична енциклопедія : в 6 т. / відп. ред. Ю.С. Шемчушенко. Київ : Укр.енцикл., 1998. T. I. C. 640.

18. Джефкинс Ф., Ядин Д. Паблик рилейшнз : учебное пособие для вузов / пер. с англ. под ред. Б.Л. Еремина. Москва : ЮНИТИ-ДАНА, 2003. С. 56.

19. Як ознайомитися із судовим рішенням? / Автор-упорядник Т.В. Руда ; за редакцією К.ю.н., доц. О.Ю. Костюченко. Видання перероблене та доповнене. Київ, 2016. 35 с.

20. Фулей T.I. Застосування практики Європейського суду 3 прав людини при здійсненні правосуддя: Науково-методичний посібник для суддів. 2-ге вид., випр., допов. Київ, 2015. С. 46.

21. Угода про асоціацію між Україною, з однієї сторони, та Європейським Союзом, Європейським співтовариством з атомної енергії і їхніми державами-членами, з іншої сторони : Міжнародний документ від 27 червня 2014 р. (у редакції від 30 листопада 2015 р.). База даних «Законодавство України». URL: http://zakon.rada.gov.ua/laws/show/984_011.

22. Конституція Польської Республіки / з передмовою В.М. Шаповала. Київ : Москаленко О.М., 2018. С. 24.

23. Rozdział 42Art. 335,356 ; Art. 365 Rozdział 43; Kodeks postępowania karnego Dz.U.2018.1987 t.j. - wersja od: 8 lipca 2019 r. URL: https://sip.lex.pl/akty-prawne/dzu-dziennikustaw/kodeks-postepowania-karnego-16798685. 